\title{
Sources and Acknowledgments
}

I gratefully acknowledge the following for permission to reprint my essays.

"The Hypothetical Imperative" was originally published in The Philosophical Review 82 (I973): 429-50. It is reprinted by permission of the publisher.

"Humanity as an End in Itself" was originally published in Ethics 9I (I980): 84-90, (C) I980 by the University of Chicago. Reprinted here by permission of the publisher.

"The Kingdom of Ends" first appeared in Proceedings of the Third International Kant Congress, edited by Lewis White Beck (Dordrecht, Holland: D. Reidel, 1972), pp. 307-1 5. Reprinted by permission of Kluwer Academic Publishers, P.O. Box I7, 3300 AA Dordrecht, Holland.

"Kant's Utopianism." Akten des 4. Internationalen KantKongresses, Mainz, 1974, Teil II.2, pp. 9I 8-24. Edited by Gerhard Funke. Berlin and New York: Walter de Gruyter.

"The Kantian Conception of Autonomy." From The Inner Citadel: Essays on Individual Autonomy, edited by John Christman. Copyright (C) I 989 by Oxford University Press, Inc. Reprinted by arrangement.

"Kant's Argument for the Rationality of Moral Conduct" was originally published in Pacific Philosophical Quarterly 66, nos. I \& 2 (January-April I985): 3-23. Reprinted by permission of the publisher. 
"Kant's Theory of Practical Reason." Copyright (C) I989, The Monist, Box 600, La Salle, Ill. 6I 301. Reprinted by permission.

"Kant on Imperfect Duty and Supererogation" was originally published in Kant Studien, I97I, pp. 55-76. It is reprinted here by permission of the publisher.

"Kant's Anti-Moralistic Strain" was originally published in Theoria 44 (I978): I3 I-5I. It is reprinted here by permission of the publisher.

"Making Exceptions without Abandoning the Principle: or How a Kantian Might Think about Terrorism." From Violence, Terrorism, and Justice, edited by Ray Frey and Christopher Morris. Copyright I99I Cambridge University Press. Reprinted by permission of the publisher.

"Kantian Constructivism in Ethics" first appeared in Ethics 99 (1989): $752-70$, (C) 1989 by the University of Chicago. It is reprinted here (with minor editorial changes) by permission of the publisher.

During the time when these essays were written, I received financial and other institutional support from the University of California, Los Angeles (1968-84), the National Endowment for the Humanities (1972-73), the National Humanities Center (198283), and the University of North Carolina, Chapel Hill (I 984-9I). This support is gratefully acknowledged.

The notes accompanying each essay acknowledge the help of various individuals, but my philosophical debts extend significantly beyond those specific acknowledgments. Former teachers who stimulated and influenced my thinking about Kant's ethics were Roderick Firth, H. H. Cox, and especially John Rawls. Among the contemporary philosophers from whose writings on Kant I have learned are Henry Allison, Karl Ameriks, Rudiger Bittner, L. W. Beck, Alan Donagan, Stephen Engstrom, David Falk, Dieter Henrich, Barbara Herman, Christine Korsgaard, Jeffrey Murphy, Onora O'Neill, Andrews Reath, John Rawls, Jerome Schneewind, John Silber, and Allen Wood. Colleagues, students, and friends at U.C.L.A., U.N.C., and elsewhere have given me helpful comments and encouragement. Tyler Burge, Jan and Bernard Boxill, David Falk, Gerald Postema, and Geoffrey Sayre McCord have been especially helpful as colleagues and 
friends. I am grateful to Karánn Durland for her fine work as a research assistant and to the Philosophy Department staff for their help. Special thanks are due to family members for their goodwill and support for many years and most particularly to Robin.

T. E. H. 
